\title{
Uptake and mitochondrial dysfunction of alpha-synuclein in human astrocytes, cortical neurons and fibroblasts
}

\author{
Nady Braidy ${ }^{1,2}$, Wei-Ping Gai ${ }^{3}$, Ying Hua X ${ }^{2,4}$, Perminder Sachdev ${ }^{1,5}$, Gilles J Guillemin ${ }^{6,7}$, Xing-Mai Jiang ${ }^{8}$,

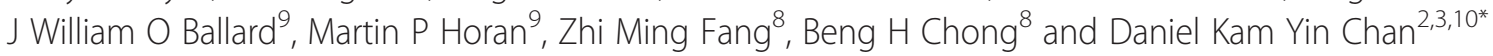

\begin{abstract}
The accumulation and aggregation of alpha-synuclein (a-syn) in several tissue including the brain is a major pathological hallmark in Parkinson's disease (PD). In this study, we show that a-syn can be taken up by primary human cortical neurons, astrocytes and skin-derived fibroblasts in vitro. Our findings that brain and peripheral cells exposed to a-syn can lead to impaired mitochondrial function, leading to cellular degeneration and cell death, provides additional evidence for the involvement of mitochondrial dysfunction as a mechanism of toxicity of a-syn in human cells.
\end{abstract}

Keywords: Alpha-synuclein, Neurons, Astrocytes, Fibroblasts, Mitochondria

\section{Introduction}

Parkinson's disease (PD) is the second most common neurodegenerative disorder after Alzheimer's disease (AD) [1]. This debilitating degenerative movement disorder is characterized symptomatically by resting tremor, bradykinesia, muscle tone rigidity and impaired autonomic, sensory and cognitive function. These motor deficits are attributed to the selective loss of dopaminergic neurons projecting from the substantia nigra to the midbrain. Dystrophic neurons typically contain cytosolic protein aggregates ("Lewy bodies") composed largely of the presynaptic protein alphasynuclein [1]. While numerous neurotoxins and genes have been implicated in the development of PD, the exact aetiology of PD remains unclear [1-5]. Accumulative evidence suggests that $\alpha$-syn may be involved in the initiation and disease progression [6,7]. Familial forms of PD are associated with either missense of gene mutations in the SNCA gene encoding for $\alpha$-syn [8]. Mutations in the $\alpha$ syn gene locus represents an important risk factor for PD in several genome-wide association studies using large cohorts worldwide [9].

\footnotetext{
* Correspondence: Daniel.Chan@sswahs.nsw.gov.au

${ }^{2}$ Aged Care and Rehabilitation, Bankstown-Lidcombe Hospital, Sydney, Australia ${ }^{3}$ Department of Human Physiology and Centre for Neuroscience,

Flinders University School of Medicine, Adelaide, Australia

Full list of author information is available at the end of the article
}

The $\alpha$-syn is a cytosolic protein that can be released from neuronal cells in small amounts via unconventional exocytosis under normal physiological conditions $[10,11]$. However, in the presence of several stressors, $\alpha-$ syn may be released from neuronal cells into the surrounding extracellular space in larger quantities and taken up by neighbouring cells by endocytosis $[10,11]$. However, little is known regarding the effect of human recombinant $\alpha$-syn on other cells of the brain and surrounding tissue.

In this study, we have shown that human recombinant $\alpha$-syn can be taken up by human primary astrocytes, cortical neurons and fibroblasts. We also show that this may lead to increased intracellular oxygen consumption and cell death after 24 hour exposure. The effect of $\alpha$ syn in vitro, even in cultured fibroblasts, suggests that PD may be a systemic illness, with primary pathological changes occurring in the brain.

\section{Materials and methods}

Reagents and chemicals

Dulbecco's phosphate buffer solution (DPBS) and all other cell culture media and supplements were from Invitrogen (Melbourne, Australia) unless otherwise stated. Mouse $\mathrm{mAb}$ anti- $\alpha$-syn, DAPI, and pAb anti-GFAP were obtained from Sigma-Aldrich (Castle-Hill, Australia). Rabbit anti- 
MAP2 and anti-fibronectin were obtained from Millipore (Melbourne, Australia). Secondary anti-mouse IgG and anti-rabbit Alexa 488 (green) or Alexa 594 (red)-conjugated antibodies were purchased from Molecular Probes (Eugene, OR). All commercial antibodies were used at the concentrations specified by the manufacturers.

\section{Cell cultures}

Human foetal brains, and skin were obtained from 16-19 week old foetuses collected following therapeutic termination with informed consent. Mixed brain cultures were prepared and maintained using a protocol previously described [12].

Astrocytes were prepared from the mixed brain cell cultures using a protocol previously described [13]. Cells were cultured in medium RPMI 1640 (Invitrogen) supplemented with $10 \%$ foetal bovine serum, $1 \% 1$-glutamax, $1 \%$ antibacterial/antifungal, and $0.5 \%$ glucose. Cells were seeded into 24-well tissue culture plates to a density of $1 \times 10^{5}$ cells 24 hours prior to experimentation.

Human foetal cortical neurons were prepared from mixed brain cell cultures as previously described [14]. Briefly, cortical neurons were plated in 24-well culture plates coated with Matrigel (BD Biosciences) diluted $1 / 20$ in Neurobasal (Invitrogen). The culture medium was changed every second day and consisted of Neurobasal medium supplemented with $1 \%$ B-27 supplement, $1 \%$ Glutamax, $1 \%$ antibiotic/antifungal, and $0.5 \%$ glucose.

Fibroblasts were prepared from the skin using a protocol as previously described [15]. All cell cultures were maintained in an incubator at $37^{\circ} \mathrm{C}$ in a humidified atmosphere containing $95 \%$ air $/ 5 \% \mathrm{CO}_{2}$.

\section{Uptake of recombinant extracellular a-synuclein}

Recombinant $\alpha$-synuclein was expressed in Escherichia coli BL21(DE3) transformed with the pET11d vector containing the human $\alpha$-synuclein cDNA described previously [16]. For uptake of recombinant $\alpha$-syn in primary astrocytes, cortical neurons and skin-derived fibroblasts, human $\alpha$-syn was incubated overnight at $37^{\circ} \mathrm{C}$ to form oligomers and then labelled with Alexa Fluor 488 (Invitrogen) as per the manufacturer's instructions. Cells were incubated with expansion media containing $1 \mu \mathrm{M}$ Alexa-Fluor-488-labelled $\alpha$-syn for $30 \mathrm{~min}$ and $60 \mathrm{~min}$. Cells were washed twice with PBS to ensure that the uptake of exogenous $\alpha$-syn was not due to non-specific binding of $\alpha$-syn to the cells.Cells were fixed with $4 \%$ paraformaldehyde diluted in DPBS.

\section{Immunocytochemistry for the detection of a-syn uptake}

The method for immunocytochemistry has been previously described [17]. Cells were incubated with selected primary antibody $\mathrm{mAb} \alpha$-syn, together with phenotypic markers (GFAP, MAP-2, Fibronectin) and antibody against the inner mitochondrial membrane protein, complex V (ATPase) (Abcam). Selected secondary antibodies (goat anti-mouse IgG or goat anti-rabbit coupled with Alexa 488 or Alexa 594) were used. The following controls were performed for each labelled experiment: (1) isotypic antibody controls; and (2) incubation with only the secondary labelled antibody.

\section{Extracellular LDH activity as a measurement for cytotoxicity}

The release of lactate dehydrogenase (LDH) into culture supernatant correlates with the amount of cell death and membrane damage, providing an accurate measure of cellular toxicity. LDH activity was assayed on cortical neurons, astrocytes and skin-derived fibroblasts treated with $5 \mu \mathrm{M}$ recombinant $\alpha$-syn after 24 hours incubation using a standard spectrophotometric technique described by [18].

\section{XF24 Microplate-based respirometry}

To determine the effect of exogenous recombinant $\alpha$-syn $(5 \mu \mathrm{M})$ on oxygen consumption rates (OCRs; as indicator of mitochondrial respiration) in cortical neurons, primary astrocytes, and skin-derived fibroblasts, the Seahorse XF24, extracellular flux analyzer (Seahorse Bioscience, North Billerica, MA, USA) was employed as previously described. Briefly, culture plates were incubated in a $\mathrm{CO}_{2}$ free incubator at $37^{\circ} \mathrm{C}$ for $1 \mathrm{hr}$ to equilibrate for temperature and $\mathrm{pH}$. The microplate was then loaded into the XF24 and further incubated for $15 \mathrm{~min}$ by $3 \mathrm{~min} \mathrm{mix}$, 2 min wait cycles before commencement of the assay. The XF assay was performed as previous described [19]. After determination of the basal respiration in the cell culture, oligomycin $(2 \mu \mathrm{M})$, carbonylcyanide-p-trifluoromethoxyphenylhydrazone (FCCP, $500 \mathrm{nM})$, and antimycin $(3 \mu \mathrm{M})$ were sequentially added and the oxygen consumption rates (OCRs) for each culture well were quantified for 2 minutes. This allowed us to determine the basal control ratio (BCR) and the uncoupling ratio (UCR) [20]. Essentially, the $\mathrm{BCR}$ is a measurement of how close the basal level of respiration is to the maximum level of respiration (i.e., basal/maximum). The closer this ratio is to 1 , the lower the maximum level of respiration, and thus represents an indication of mitochondrial malfunction. The UCR is a measurement of mitochondrial functional integrity and measures the ratio of uncoupled to physiologically normal respiration levels (i.e., maximum/basal). The greater the maximum level of respiration, the greater the mitochondrial functional integrity.

Bradford protein assay for the quantification of total protein Extracellular LDH activity, $\mathrm{NAD}^{+}$concentration, nuclei and mitochondrial protein content, and mitochondrial function were corrected for variations in protein concentration using the Bradford protein assay described by Bradford [21]. 


\section{Data analysis}

Results obtained are presented as the means \pm the standard error of measurement (SEM). One way analysis of variance (ANOVA) and post hoc Tukey's multiple comparison tests were used to determine statistical significance between treatment groups. Differences between treatment groups were considered significant if $\mathrm{p}$ was less than $0.05(\mathrm{p}<0.05)$. Experiments were performed in triplicates using cells derived from three different specimens unless otherwise stated.

\section{Results}

Time dependent uptake of a-syn in cultured human cortical neurons, astrocytes and skin-derived fibroblasts To reaffirm the uptake of extracellular $\alpha$-syn aggregates in human astrocytes, cortical neurons and fibroblasts, primary cultures were incubated with cell culture media containing Alexa-Fluor-488 labelled $\alpha$-syn. Immunofluorescence analysis displayed in this study have highlighted the potential ability of these cell to uptake $\alpha$ syn in a time-dependent manner (Figures 1, 2 and 3).

Cytotoxic effects of a-syn in enteric neurons is associated increased intracellular oxygen consumption leading to cell death

A recently study showed that recombinant extracellular $\alpha$-syn forms cytoplasmic bodies capable of inducing toxicity at $5 \mu \mathrm{M}$ after 24 hours incubation in SH-SY5Y neuroblastoma cell line [22]. Using the same dose and exposure time, we investigated the cytotoxic effect of recombinant $\alpha$-syn in human astrocytes, cortical neurons and fibroblasts. A significant increase in basal control

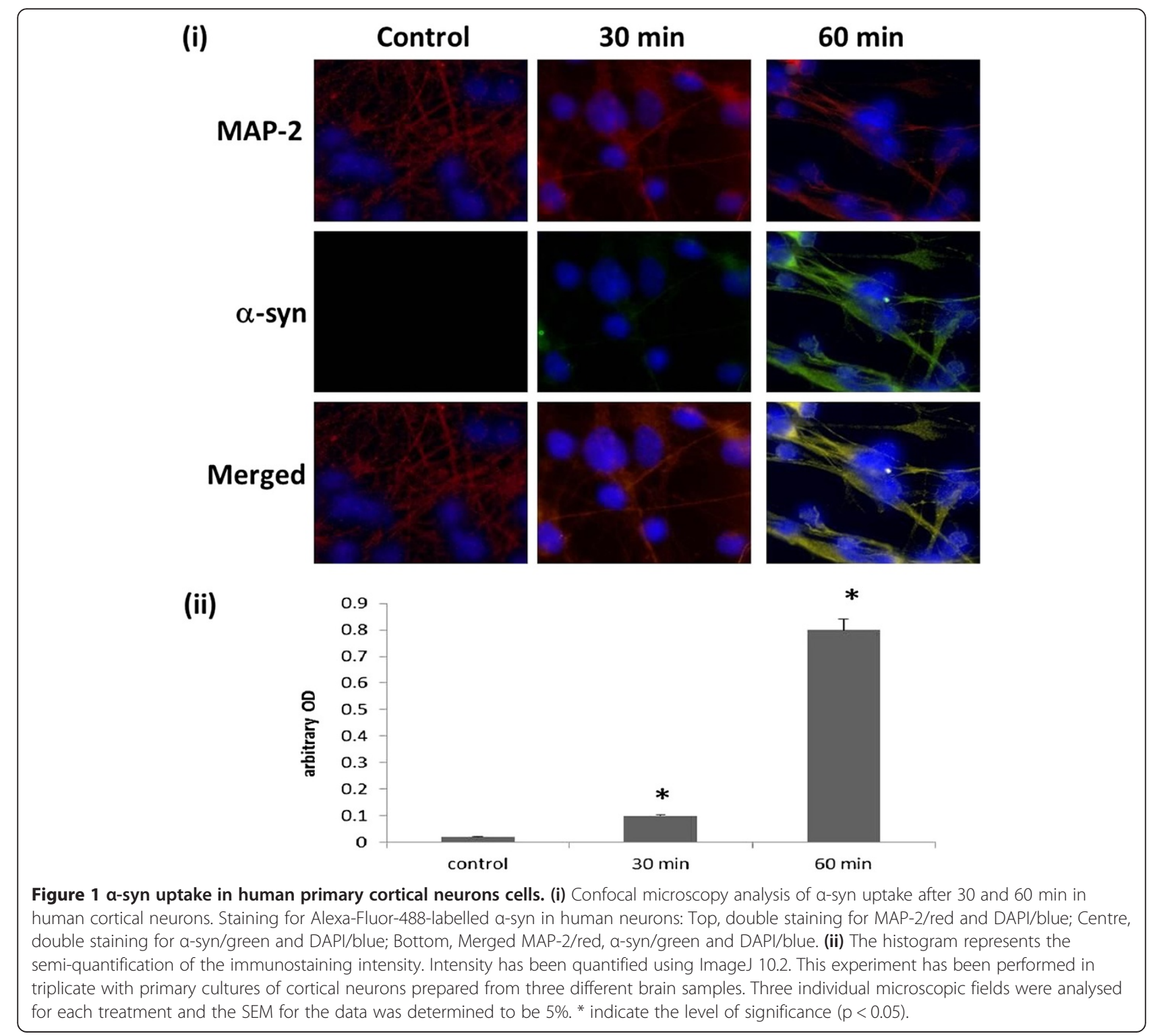




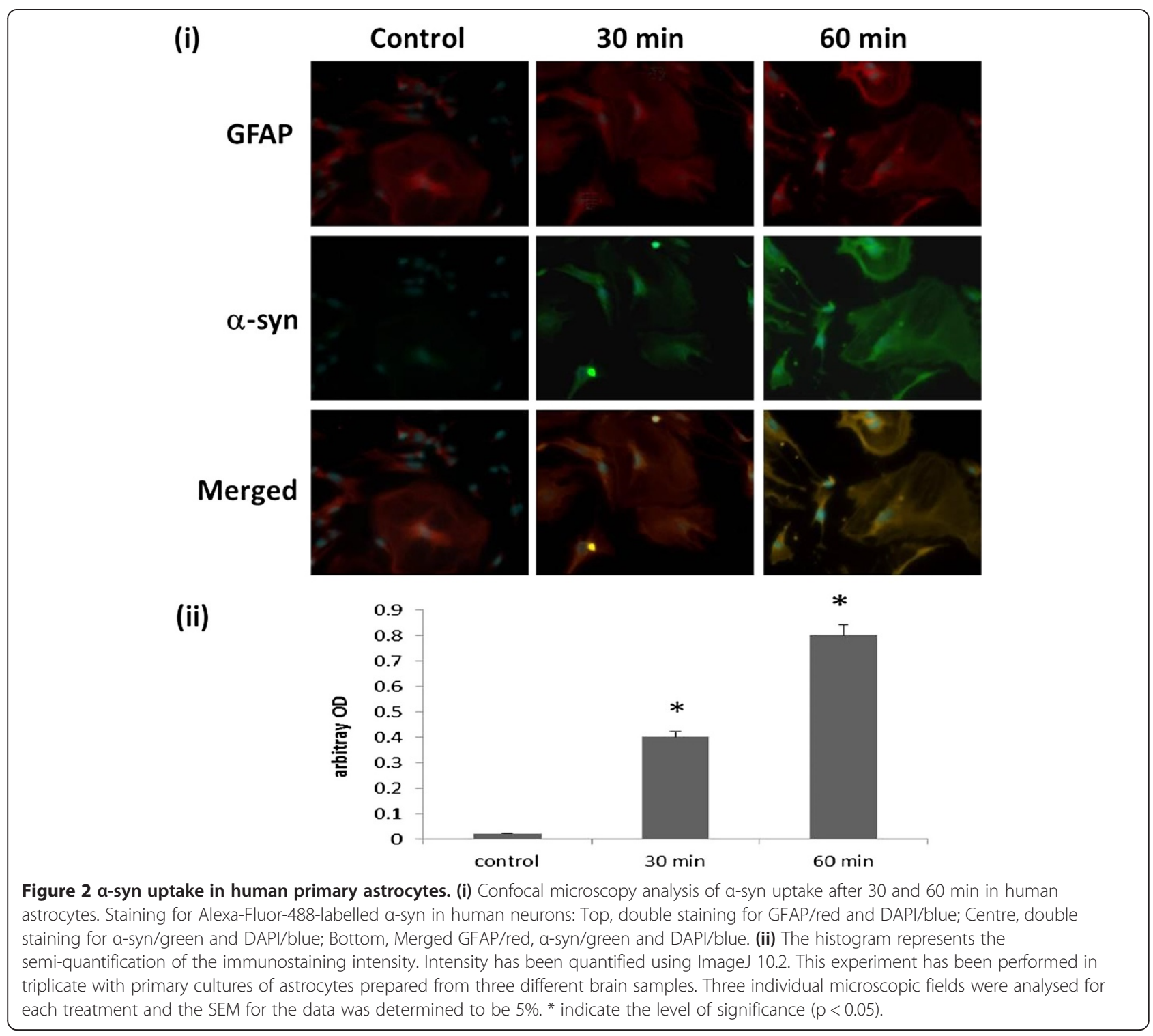

ratio (BCR) and a decline in uncoupling ratio (UCR) was observed after 24 hours incubation when these cells were treated with medium containing recombinant $\alpha$-syn using the Seahorse XF24 (Seahorse Bioscience) (Figure 4). We further confirmed that $\alpha$-syn is cytotoxic to the mitochondria by demonstrating that exogenous $\alpha$-syn is localised in the mitochondria of the host cell (Figure 5). Increased extracellular LDH activity was also observed in these cells after 24 hours (Figure 6).

\section{Discussion}

The current study uses several cell culture models: 1 ) to reaffirm whether recombinant $\alpha$-syn can be taken up by primary human astrocytes, cortical neurons and fibroblasts; 2 ) to determine the effect of $\alpha$-syn on mitochondrial function in brain and periphery cells using Seahorse XF240. A key finding of the current investigation is that $\alpha$-syn can accumulate in several cell types in vitro not restricted to the brain, in a time dependent manner leading to increased intracellular oxygen consumption and cell death.

Owing to the diverse clinical symptoms associated with $\mathrm{PD}$, it is likely that multiple brain systems may be impaired. Indeed, Lewy bodies are widely distributed in the several areas of the brain, including the midbrain, cerebrum and brainstem corresponding to axonal projections [23]. Earlier studies have suggested that misfolded $\alpha$-syn may propagate from neuron to neuron in a prion-like manner, causing endogenous $\alpha$-syn to misfold [11]. Recently, Freundt et al. [24] showed that fibrillar $\alpha$-synuclein can be internalized by primary mouse neurons via rapid axonal transport with saltatory movement [24]. Moreover, Angot et al. [25] showed that $\alpha$-syn can be transferred between neuronal host cells and grafted dopaminergic neurons in vivo [25]. However, our data is the first to 


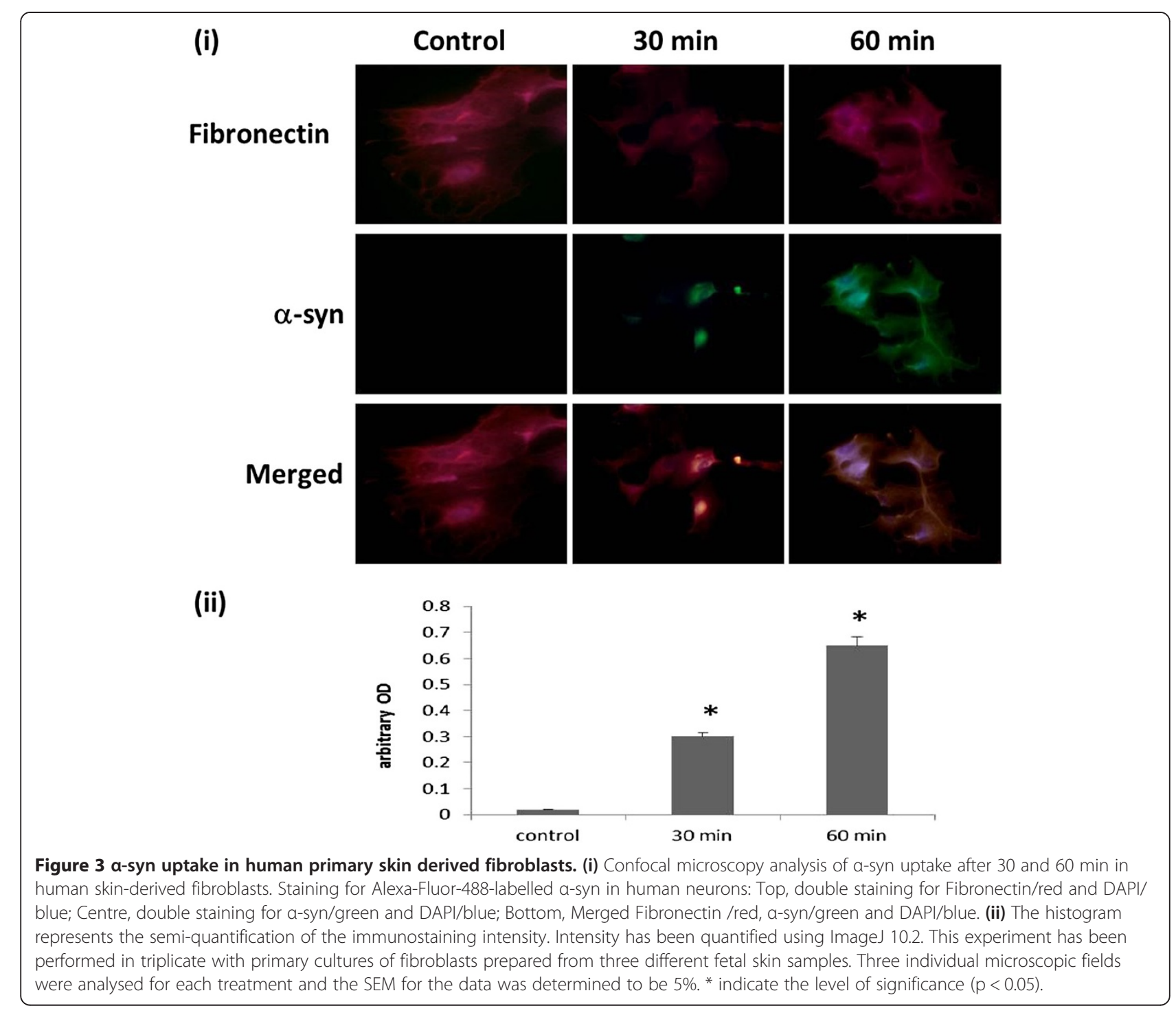

(i)

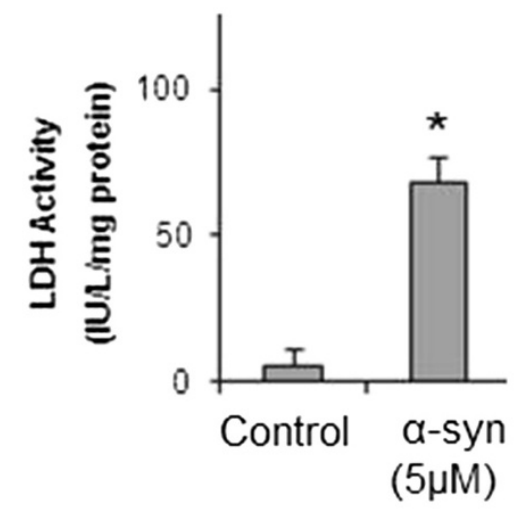

(ii)

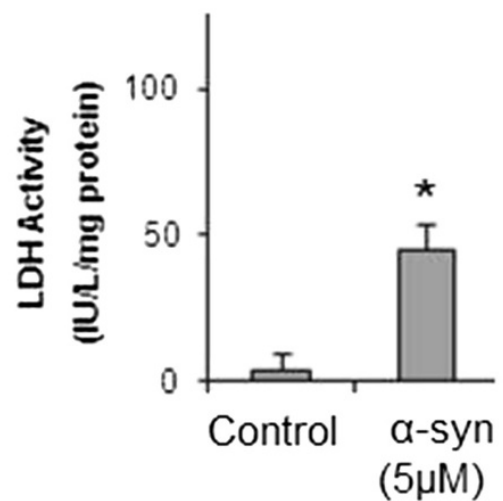

(iii)

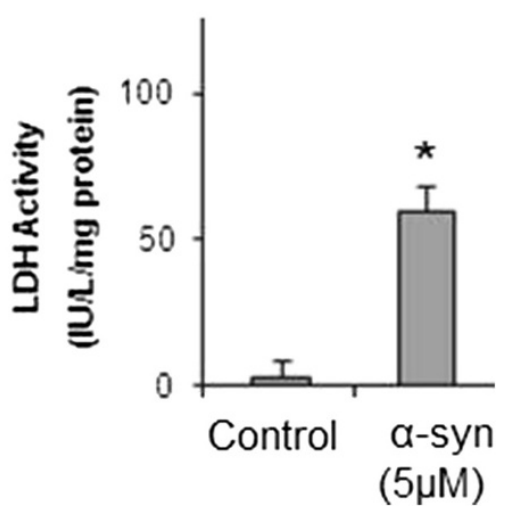

Figure 4 Effects of a-syn on mitochondrial function in human primary cortical neurons, astrocytes and skin-derived fibroblasts. The BCR and UCR were determined in (i) human primary cortical neurons, (ii) astrocytes and (iii) skin-derived fibroblasts pre-treated with $5 \mu M$ recombinant a-syn for 24 hours. Significance ${ }^{*} p<0.05$ compared to non-treated cells. ( $n=4$ for each treatment group). 


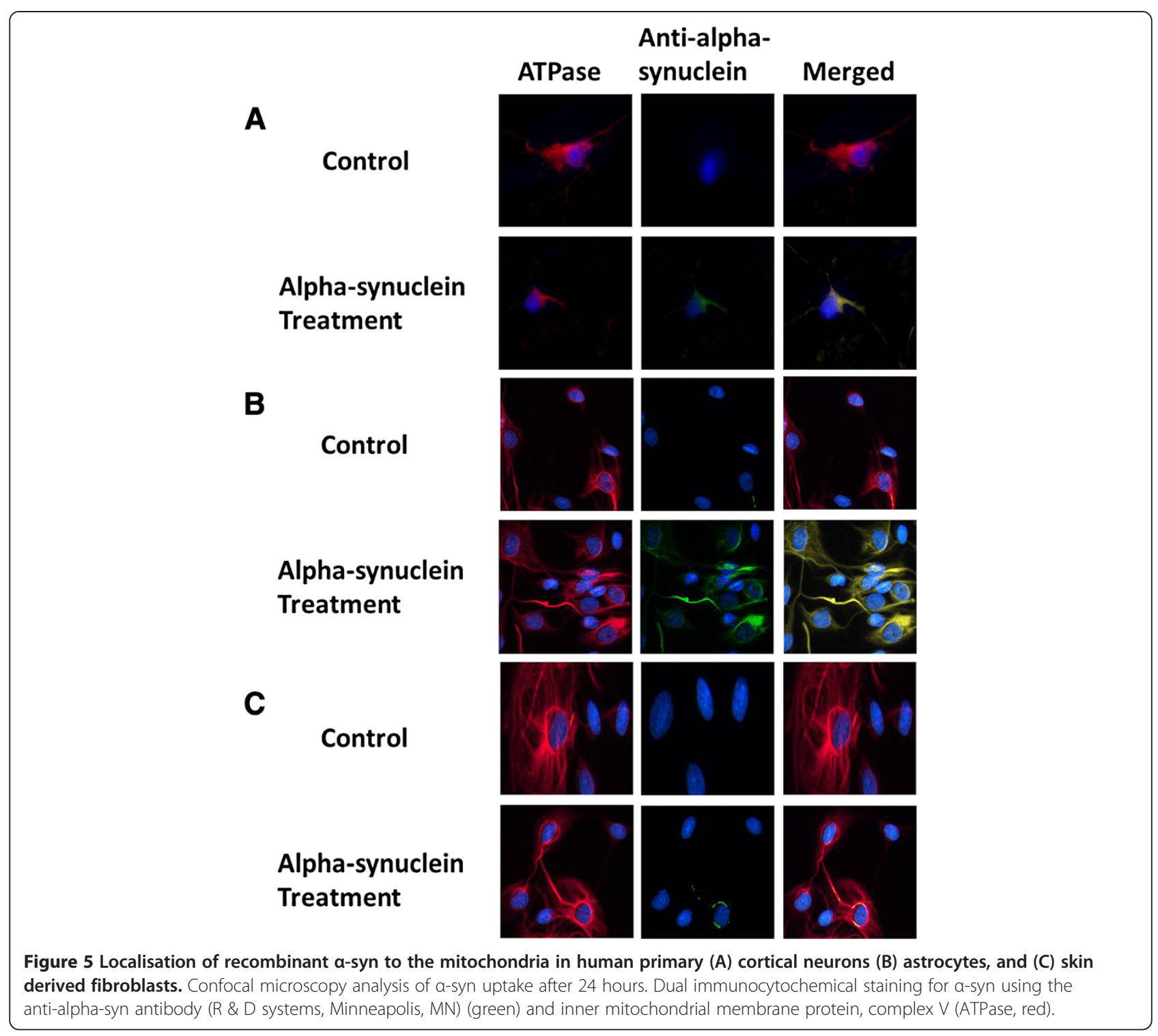

demonstrate the uptake of exogenous $\alpha$-syn oligomers in human primary cortical neurons. Taken together, these results support the hypothesis that PD can be caused by neuron-to-neuron spread of $\alpha$-syn aggregates involving axonal transport of fibrillar and/or oligomers.

Glial inclusions, which are common pathological features in PD, have been shown to occur as a result of neuron-to-glia transmission of $\alpha$-syn protein [26]. Here, we show that human primary astrocytes can also uptake $\alpha$-syn oligomers similar to murine glial cells. One study showed that glial accumulation of $\alpha$-syn proteins released from murine neuronal cells may involve endocytosis leading to the formation of cytoplasmic inclusion bodies [27]. Furthermore, astrocytes exposed to neuronal $\alpha$-syn exhibited significant changes in their gene expression profile providing biochemical evidence for an inflammatory response. Up-regulation of pro-inflammatory cytokines and chemokines correlated positively with the degree of accumulation of $\alpha$-syn in glial cells [26]. Together, these results suggest that astroglial alpha-synuclein pathology is produced by direct transmission of neuronal alpha-synuclein aggregates, causing inflammatory responses. This transmission step is thus an important mediator of pathogenic glial responses and could qualify as a new therapeutic target.

Our data is also in line with previous studies showing increased $\alpha$-syn expression in Parkinson patient fibroblasts parallel to increased oxidative stress in these cells [28]. Without an appropriate mechanism of uptake into these distinct cell types, these observed patterns cannot be fully evaluated. They do, however, suggest that $\alpha$-syn toxicity may not be restricted to the central and peripheral nervous system but may also be associated with other systems such as the skin. For example, it might be reasonable to hypothesise that $\alpha$-syn aggregates can 
(i)

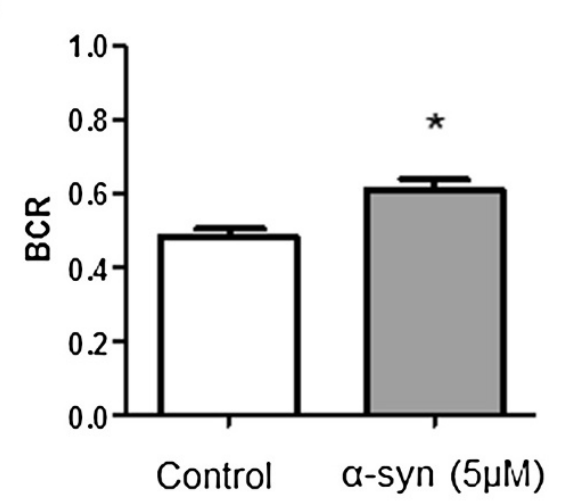

(ii)

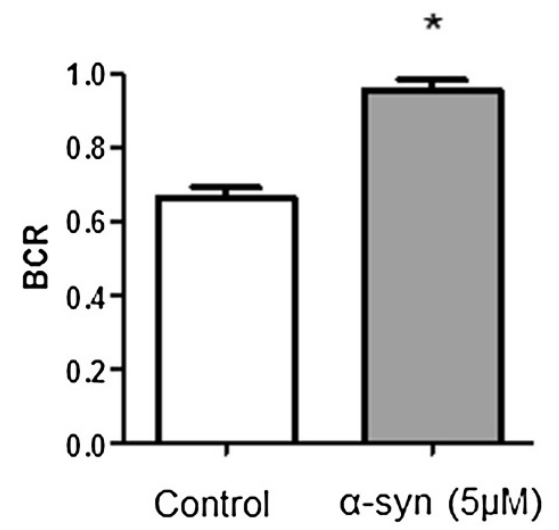

(iii)

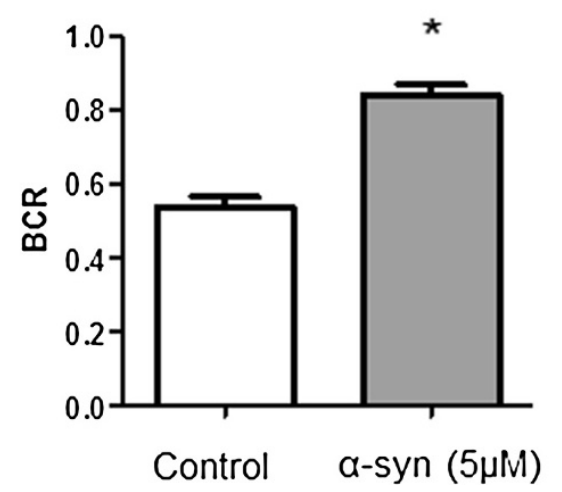

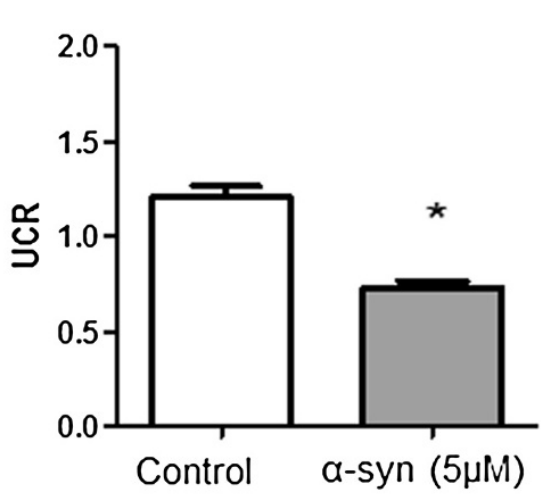

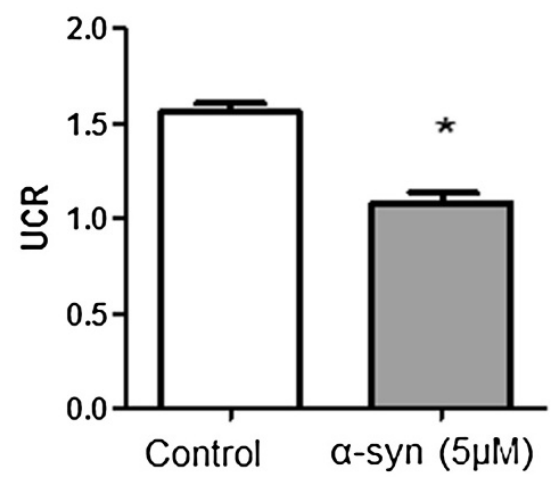

Figure 6 Effects of a-syn on cell viability in human primary cortical neurons, astrocytes and skin-derived fibroblasts. Effect of recombinant a-syn (5 $\mu \mathrm{M})$ on extracellular $\mathrm{LDH}$ activity in (i) human primary cortical neurons, (ii) astrocytes and (iii) skin-derived fibroblasts pre-treated with $5 \mu \mathrm{M}$ recombinant $\mathrm{a}$-syn for 24 hours. ${ }^{*} \mathrm{p}<0.05$ compared to non-treated cells (control); $(\mathrm{n}=4$ for each treatment group).

progress from neurons, and dissociate to interact with other cells, and vice versa, hence leading to a reduction in function which is not restricted to neuronal cells.

Mitochondrial dysfunction has been frequently documented in the neurodegenerative process that underlies PD [10,28-35]. Despite this, the molecular events leading to the observed dysfunction remains unclear. The goal of this study was also to investigate the effects of recombinant $\alpha$-syn cell viability and mitochondrial function in primary human neurons, astrocytes and fibroblasts. Our data shows a significant increase in lactate dehydrogenase $(\mathrm{LDH})$ release and indicating a reduction in cell viability in $\alpha$-syn treated cells compared to non-treated controls. With regards to mitochondrial function, $\alpha$-syn exhibited a significant reduction in oxygen consumption in these cells, as observed by an increase in the BCR ratio and a decline in the UCR. Importantly, these data also support a previous PD respiratory analysis study 
which found that $\alpha$-syn over-expression also reduced the mitochondrial maximum respiration rate and increased mitochondrial fragmentation [34].

While $\alpha$-syn is a well known cytoplasmic protein, numerous studies have shown that it has some affinity to phospholipids, and vesicles [36,37]. Herein we have shown that $\alpha$-syn is also delivered to the mitochondria. Another study has shown that $\alpha$-syn is present in nanomolar concentrations in neuronal culture medium [38]. Secreted forms of $\alpha$-syn have been shown to re-enter adjacent cells leading to increased cytotoxicity via oxidative stress mechanisms $[22,25]$. In the present study, we showed that, in cultured neurons, glial cells and skin-derived fibroblasts, $\alpha$-syn could form intracellular inclusions. Our study does not rule out the possibility that the internalized recombinant $\alpha$-syn may be entangled with endogenous $\alpha$-syn, and that the $\alpha$-syn expression visualised herein may consist of both naturally occurring endogenous and recombinant exogenous $\alpha$-syn. However, using our method, it is clear that endogenous $\alpha$-syn is only expressed at very low levels in foetal tissue, and not detected using immunohistochemistry. Further work is warranted to investigate the binding properties of $\alpha$-syn in cultured human cells.

The current data is consistent with mitochondrial dysfunction as the converging pathway connecting a variety of causes for PD. In fact, several causes of mitochondrial dysfunction due to free radicals and lysosomal/proteasome dysfunction associated with $\alpha$-syn have been reported in PD $[28,39,40]$. One study showed a higher frequency in somatic mitochondrial DNA deletion in the substantia nigra of sporadic PD patients leading to deficiency in the respiratory chain and increased generation of reactive oxygen species [41]. These results are in line with our current work indicating that PD may occur in response to mitochondrial dysfunction, possibly due to alterations in gene expression.

\section{Competing interest}

The authors declare that they have no competing interest.

\section{Authors' contributions}

Conceived and designed the experiments: NB and DKYC. Analyzed the data: $N B, Y H X, M P H$ and ZMF. Wrote the first draft of the manuscript: NB. Contributed to the writing of the manuscript: NB, YHX, MPH, PS, GJG and DKYC. Agree with manuscript results and conclusions: NB, YHX, MPH, PS, GJG, BHC, X-MJ, JWOB and DKYC. Made critical revisions and approved final version: NB, YHX, DKYC. All authors read and approved the final manuscript.

\section{Acknowledgements}

This work was supported by the UNSW Faculty of Medicine Research Grant to Dr Nady Braidy. Dr Nady Braidy is also the recipient of an Alzheimer's Australia Viertel Foundation and the National Health and Medical Research Council Early Career Research Fellowship at the University of New South Wales. This work has been also supported by the Alzheimer's Association (grant\#IIRG- 08-89545) and by the Rebecca Cooper foundation (Australia).

\section{Author details}

${ }^{1}$ Centre for Healthy Brain Ageing, School of Psychiatry, University of New South Wales, Sydney, Australia. ${ }^{2}$ Aged Care and Rehabilitation,

Bankstown-Lidcombe Hospital, Sydney, Australia. ${ }^{3}$ Department of Human
Physiology and Centre for Neuroscience, Flinders University School of Medicine, Adelaide, Australia. ${ }^{4}$ Faculty of Medicine, University of New South Wales, Sydney, Australia. ${ }^{5}$ Neuropsychiatric Institute, Prince of Wales Hospital, Sydney, Australia. ${ }^{6}$ School of Medical Sciences, University of New South Wales, Sydney, Australia.

${ }^{7}$ St Vincent's Centre for Applied Medical Research, Sydney, Australia. ${ }^{8}$ St George Clinical School, University of New South Wales and St George Hospital, Sydney, Australia. ${ }^{9}$ School of Biotechnology and Biomolecular Sciences, University of New South Wales, Sydney, Australia. ${ }^{10}$ Aged Care and Rehabilitation Unit, Bankstown-Lidcombe Hospital, Eldridge Road, Bankstown 2031, NSW, Australia.

Received: 3 June 2013 Accepted: 1 October 2013

Published: 4 October 2013

References

1. Fahn S, Sulzer D: Neurodegeneration and neuroprotection in Parkinson disease. NeuroRx 2004, 1(1):139-154.

2. Keeney P, Xie J, Capaldi R, Benenett J: Parkinson's disease brain mitochondrial complex I has oxidatively damaged subunits and is functionally impaired and misassembled. J Neurosci Res 2006, 26:5256-5264.

3. Goetze O, Woitalla D: The role of MPTP in Parkinson's disease: connecting brain and gut? Exp Neurol 2008, 210(2):281-285.

4. Halliday G, McCann H: Human-based studies on alpha-synuclein deposition and relationship to Parkinson's disease symptoms. Exp Neurol 2008, 2008:12-21.

5. Lesage S, Brice A: Parkinson's Disease: from monogenic forms to genetic susceptibility factors. Hum Mol Genet 2009, 18:R48-R59.

6. Spillantini M, Schmidt M, Lee V, Trojanowski J, Jakes R, Goerdert M: Alpha-synuclein in lewy bodies. Nature 1997, 388:839-840.

7. Spillantini MG, Crowther RA, Jakes R, Hasegawa M, Goedert M: Alpha-synuclein in filamentous inclusions of lewy bodies from Parkinson's disease and dementia with lewy bodies. Proc Natl Acad Sci USA 1998, 95(11):6469-6473.

8. Wider C, Ross OA, Nishioka K, Heckman MG, Vilarino-Guell C, Jasinska-Myga B, Erketin-Taner N, Rademakers R, Graff-Radford NR, Mash DC, Papapetropoulos S, Duara R, Uchikado H, Wszolek ZK, Farrer MJ, Dickson DW: An evaluation of the impact of MAPT, SNCA and APOE on the burden of Alzheimer's and lewy body pathology. J Neurol Neurosurg Psychiatry 2012, 83(4):424-429.

9. Polymeropoulos MH, Lavedan C, Leroy E, Ide SE, Dehejia A, Dutra A, Pike B, Root H, Rubenstein J, Boyer R, Stenroos ES, Chandrasekharappa S, Athanassiadou A, Papapetropoulos T, Johnson WG, Lazzarini AM, Duvoisin RC, Di lorio G, Golbe LI, Nussbaum RL: Mutation in the alpha-synuclein gene identified in families with Parkinson's disease. Science 1997, 276(5321):2045-2047.

10. Lee HJ, Patel S, Lee SJ: Intravesicular localization and exocytosis of alpha-synuclein and its aggregates. J Neurosci 2005, 25(25):6016-6024.

11. Jang A, Lee HJ, Suk JE, Jung JW, Kim KP, Lee SJ: Non-classical exocytosis of alpha-synuclein is sensitive to folding states and promoted under stress conditions. J Neurochem 2010, 113(5):1263-1274.

12. Guillemin GJ, Smythe G, Takikawa O, Brew BJ: Expression of indoleamine 2,3-dioxygenase and production of quinolinic acid by human microglia, astrocytes, and neurons. Glia 2005, 49(1):15-23.

13. Guillemin GJ, Kerr SJ, Smythe GA, Smith DG, Kapoor V, Armati PJ, Croitoru J, Brew BJ: Kynurenine pathway metabolism in human astrocytes: a paradox for neuronal protection. J Neurochem 2001, 78:1-13.

14. Guillemin GJ, Cullen KM, Lim CK, Smythe GA, Garner B, Kapoor V, Takikawa O, Brew BJ: Characterization of the kynurenine pathway in human neurons. J Neurosci 2007, 27(47):12884-12892.

15. Asp L, Johansson A-S, Mann A, Owe-Larsson B, Urbanska E, Kocki T, Kesel M, Engberg G, Lundkvist G, Karlsson H: Effects of pro-inflammatory cytokines on expression of kynurenine pathway enzymes in human dermal fibroblasts. J Inflamm 2011, 8:25.

16. Jensen PH, Islam K, Kenney J, Nielsen MS, Power J, Gai WP: Microtubule-associated protein $1 \mathrm{~B}$ is a component of cortical lewy bodies and binds alpha-synuclein filaments. J Biol Chem 2000, 275(28):21500-21507.

17. Guillemin G, Smythe G, Takikawa O, Brew BJ: Expression of indoleamine 2,3-dioxygenase and production of quinolinic acid by human microglia, astrocytes and neurons. Glia 2004, 49:15-23.

18. Koh JY, Choi DW: Quantitative determination of glutamate mediated cortical neuronal injury in cell culture by lactate dehydrogenase efflux assay. J Neurosci Methods 1987, 20:83-90. 
19. Schuh R, Clerc P, Hwang H-J, Mehrabiab Z, Bittman K, Chen H, Polster B: Adaptation of microplate-based respirometry for hippocampal slices and analysis of respiratory capacity. J Neurosci Res 2011, 89:1979-1988.

20. Pesta D, Gnaiger E: High-resolution respirometry: OXPHOS protocols for human cells and permeabilized fibers from small biopsies of human muscle. Methods Mol Biol 2012, 810:25-58.

21. Bradford MM: A rapid and sensitive method for quantitation of microgram quantities of protein utilising the principle of protein-dye binding. Anal Biochem 1976, 53:452-458.

22. Konno M, Hasegawa T, Baba T, Miura E, Sugeno N, Kikuchi A, Fiesel FC, Sasaki T, Aoki M, Itoyama Y, Takeda A: Suppression of dynamin GTPase decreases alpha-synuclein uptake by neuronal and oligodendroglial cells: a potent therapeutic target for synucleinopathy. Mol Neurodegener 2012, 7:38.

23. Braak H, Del Tredici K, Rub U, de Vos RA, Jansen Steur EN, Braak E: Staging of brain pathology related to sporadic Parkinson's disease. Neurobiol Aging 2003, 24(2):197-211.

24. Freundt EC, Maynard N, Clancy EK, Roy S, Bousset L, Sourigues Y, Covert M, Melki R, Kirkegaard K, Brahic M: Neuron-to-neuron transmission of alpha-synuclein fibrils through axonal transport. Ann Neurol 2012, 72(4):517-524

25. Angot E, Steiner JA, Lema Tome CM, Ekstrom P, Mattsson B, Bjorklund A, Brundin P: Alpha-synuclein cell-to-cell transfer and seeding in grafted dopaminergic neurons in vivo. PLoS One 2012, 7(6):e39465.

26. Lee H, Suk J, Patrick C, Bae E, Chio J, Rho S, Hwang D, Masliah E, Lee S: Direct transfer of alpha-synucelin from neuron to astroglia causes inflammatory responses in synucleinopathies. $J$ Biol Chem 2010, 285:9262-9272.

27. Lee HJ, Suk JE, Bae EJ, Lee JH, Paik SR, Lee SJ: Assembly-dependent endocytosis and clearance of extracellular alpha-synuclein. Int J Biochem Cell Biol 2008, 40(9):1835-1849.

28. Hoepken HH, Gispert S, Azizov M, Klinkenberg M, Ricciardi F, Kurz A Morales-Gordo B, Bonin M, Riess O, Gasser T, Kogel D, Steinmetz H, Auburger G: Parkinson patient fibroblasts show increased alpha-synuclein expression. Exp Neurol 2008, 212(2):307-313.

29. Schapira A, Cooper J, Dexter D, Jenner P, Marsden C: Mitochondrial complex I deficiency in Parkinson's disease. Lancet 1989, 1:1269.

30. Lin M, Beal MF: Mitochondrial dysfunction and oxidative stress in neurodegenerative diseases. Nature 2006, 443:787-795.

31. Sas K, Robotka H, Toldi J, Vecsei L: Mitochondria, metabolic disturbances, oxidative stress and the kynurenine system, with focus on neurodegenerative disorders. J Neurol Sci 2007, 257(1-2):221-239.

32. Li RH, Liu YQ, Li ZB, Yang L, Wang SW, Guan MX: Failures in mitochondrial tRNA(Met) and tRNA(GIn) metabolism caused by the novel 4401A $>G$ mutation are involved in essential hypertension in a Han chinese family. Hypertension 2009, 54(2):329-337.

33. Kim HY, Lee KY, Lu Y, Wang JG, Cui L, Kim SJ, Chung JM, Chung K: Mitochondrial $\mathrm{Ca} 2+$ uptake is essential for synaptic plasticity in pain. J Neurosci 2011, 31(36):12982-12991.

34. Nakamura K, Nemani VM, Azarbal F, Skibinski G, Levy JM, Egami K, Munishkina L, Zhang J, Gardner B, Wakabayashi J, Sesaki H, Cheng Y Finkbeiner S, Nussbaum RL, Masliah E, Edwards RH: Direct membrane association drives mitochondrial fission by the Parkinson disease-associated protein alpha-synuclein. J Biol Chem 2011, 286(23):20710-20726.

35. Lizard G, Rouaud O, Demarquoy J, Cherkaoui-Malki M, Iuliano L: Potential roles of peroxisomes in Alzheimer's disease and in dementia of the Alzheimer's type. J Alzheimers Dis 2012, 29(2):241-254.

36. Davidson WS, Jonas A, Clayton DF, George JM: Stabilization of alpha-synuclein secondary structure upon binding to synthetic membranes. J Biol Chem 1998, 273(16):9443-9449.

37. Kahle PJ, Neumann M, Ozmen L, Muller V, Jacobsen H, Schindzielorz A, Okochi M, Leimer U, van derPutten H, Probst A, Kremmer E, Kretzschmar HA, Haass C. Subcellular localization of wild-type and Parkinson's disease-associated mutant alpha-synuclein in human and transgenic mouse brain. $J$ Neurosci 2000, 20(17):6365-6373.

38. Dixon C, Mathias N, Zweig RM, Davis DA, Gross DS: Alpha-Synuclein targets the plasma membrane via the secretory pathway and induces toxicity in yeast. Genetics 2005, 170(1):47-59.
39. Budd SL, Nicholls DG: Mitochondria, calcium regulation, and acute glutramate excitotoxicity in cultured cerebellar granule cells. J Neurochem 1996, 67:2282-2291.

40. Esteves A, Arduino D, Silva D, Oliveira C, Cardoso S: Mitochondrial dysfunction: the road to alpha-synuclein oligomerisation in PD. Parkinsons Dis 2010, 2011:1-20.

41. Bender A, Krishnan KJ, Morris CM, Taylor GA, Reeve AK, Perry RH, Jaros E, Hersheson JS, Betts J, Klopstock T, Taylor RW, Turnbull DM: High levels of mitochondrial DNA deletions in substantia nigra neurons in aging and Parkinson disease. Nat Genet 2006, 38(5):515-517.

doi:10.1186/2047-9158-2-20

Cite this article as: Braidy et al:: Uptake and mitochondrial dysfunction of alpha-synuclein in human astrocytes, cortical neurons and fibroblasts. Translational Neurodegeneration 2013 2:20.

\section{Submit your next manuscript to BioMed Central and take full advantage of:}

- Convenient online submission

- Thorough peer review

- No space constraints or color figure charges

- Immediate publication on acceptance

- Inclusion in PubMed, CAS, Scopus and Google Scholar

- Research which is freely available for redistribution

Submit your manuscript at www.biomedcentral.com/submit
C) BioMed Central 